\title{
Development of Rheumatoid Arthritis after Chronic Hepatitis Caused by Hepatitis C Virus Infection
}

\author{
Shunsei Hirohata, Tetsufumi Inoue and Koji Ito
}

\begin{abstract}
We describe a patient with rheumatoid arthritis (RA) who had preceding evidence of posttransfusion, non-A, non-B hepatitis. The patient showed positive serological tests for antihepatitis $\mathrm{C}$ virus (HCV) antibody. The manifestations of $\mathrm{RA}$, including progressive polyarthritis and positive serum rheumatoid factors, emerged after the ameriolation of hepatitis and persisted for more than 3 years, indicating that the polyarthritis in this patient was not the prodrome of the hepatitis. This patient had HLA-DR4 and HLA-Bw54 which are found to be strongly associated with $\mathrm{RA}$ in Japan. It is therefore suggested that $\mathrm{HCV}$ may trigger the development of RA especially in genetically susceptible individuals.
\end{abstract}

(Internal Medicine 31: 493-495, 1992)

Key words: rheumatoid factor, HLA-Bw54, HLA-DR4

Introduction

The development of rheumatoid arthritis (RA) has been considered to involve both genetic and environmental factors (1). Thus, the association of RA with HLA-DR4 has been well appreciated irrespective of the race $(2-4)$. On the other hand, the association of arthritis with hepatitis has been well documented (5-12). The polyarthritis in most patients with viral hepatitis has been found to emerge during the prodrome of hepatitis, and to subside after the development of typical manifestations of hepatitis, resulting in no joint deformity (6). However, there has been a single case report in which the patient developed progressive RA subsequent to acute, hepatitis B surface antigen-positive, viral hepatitis (13).

Recently, a cDNA clone which was shown to encode an antigen associated with the non- $A$, non- $B$ hepatitis has been isolated $(14,15)$. This non- $A$, non- $B$ hepatitis virus, designated hepatitis $\mathrm{C}$ virus (HCV), appears to account for $70-80 \%$ of the non- $A$, non- $\mathrm{B}$ hepatitis (16). In the present report, we describe a patient who developed progressive RA after post-transfusion $\mathrm{HCV}$ infection. The possible role of $\mathrm{HCV}$ in the triggering of the development of RA in genetically susceptible individuals is discussed.

\section{Case Report}

A 55-year-old woman visited our clinic with the complaint of general malaise on April 8, 1986. She was found to have mild liver dysfunction in 1983. Laboratory examination on her visit revealed a slight elevation of serum transaminases (GOT $31 \mathrm{KU}$, GPT $25 \mathrm{KU}$ ). She had received a blood transfusion in 1957. She denied habitual intake of alcohol or drugs. Serological tests for hepatitis $A$ virus (HAV) and hepatitis $B$ virus (HBV) infection were all negative. The diagnosis of chronic hepatitis of a non- $A$, non- $B$ type was made. At this time, she did not show any joint manifestations and the RA test was negative. In July 1987, she visited our clinic again with the complaint of painful polyfocal joint swelling and morning stiffness of her hands lasting more than 3 months (Fig. 1). Physical examination revealed painful symmetrical swelling of the proximal interphalangeal (PIP), metacarpophalangeal (MCP) and knee joints. Laboratory data showed normal liver function test. The result of $\mathrm{C}$-reactive protein was $1+$ positive, and erythrocyte sedimentation rate was $51 \mathrm{~mm} / \mathrm{h}$. She was diagnosed as RA, and treatment with oral prednisolone $(2.5 \mathrm{mg} /$ day $)$ and indomethacin $(50 \mathrm{mg} /$ day) was started. Her liver function test has remained normal since July 1987. However, her RA has not been satisfactorily controlled by the additional treatment with disease modifying

From the Department of Medicine and Physical Therapy, University of Tokyo Faculty of Medicine, Tokyo

Received for publication July 2, 1991; Accepted for publication October 22, 1991

Reprint requests should be addressed to Dr. Shunsei Hirohata, the Department of Medicine and Physical Therapy, University of Tokyo Faculty of Medicine, 7-3-1 Hongo, Bunkyo-ku, Tokyo 113, Japan 


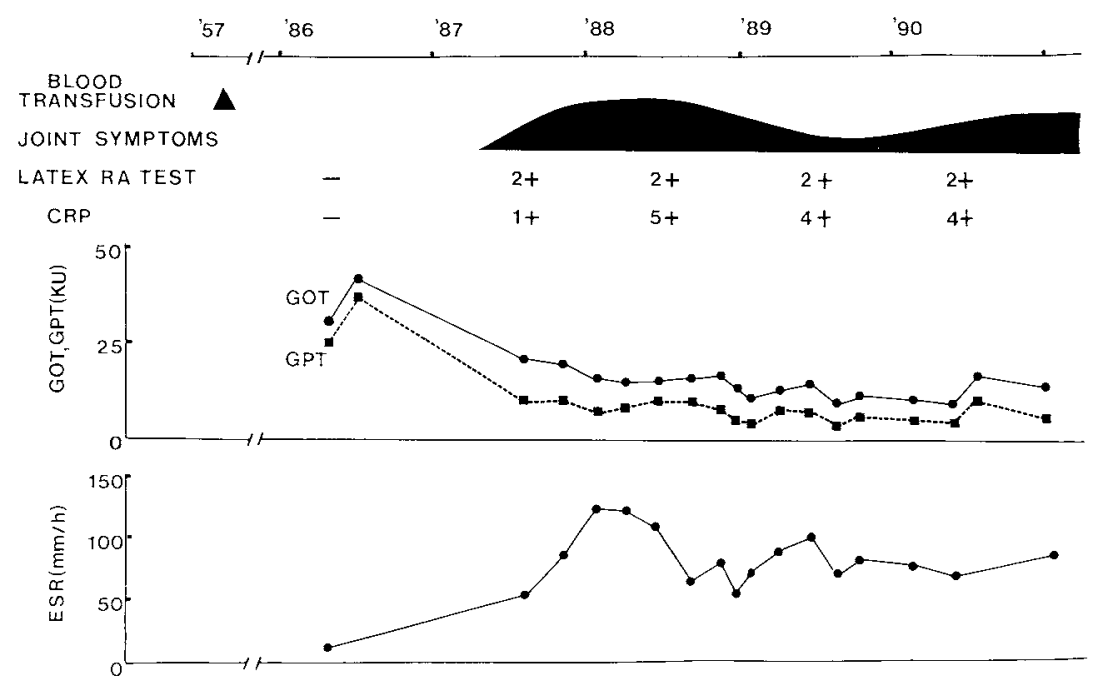

Fig. 1. Clinical course of the patient showing the development of rheumatoid arthritis (RA) after long lasting chronic hepatitis due to hepatitis $\mathrm{C}$ virus (HCV) infection.

anti-rheumatic drugs, as evidenced by the findings on roentgenograms of the joints showing remarkable erosive changes (Fig. 2). She had been diagnosed as posttransfusion non- $\mathrm{A}$, non-B hepatitis because of the negative results for $\mathrm{HBs} \mathrm{Ag}$ and anti-HBs antibody. Serological examination using an assay kit for anti-HCV antibody (Chiron Co., Emeryville CA) revealed the positive anti$\mathrm{HCV}$ antibody in the sera, indicating that her hepatitis was caused by HCV infection. The test for anti-HTLV-I antibody was negative. Although RA test turned positive when she developed active synovitis, she had shown negative serum rheumatoid factor during the phase of active hepatitis without joint manifestations. The results

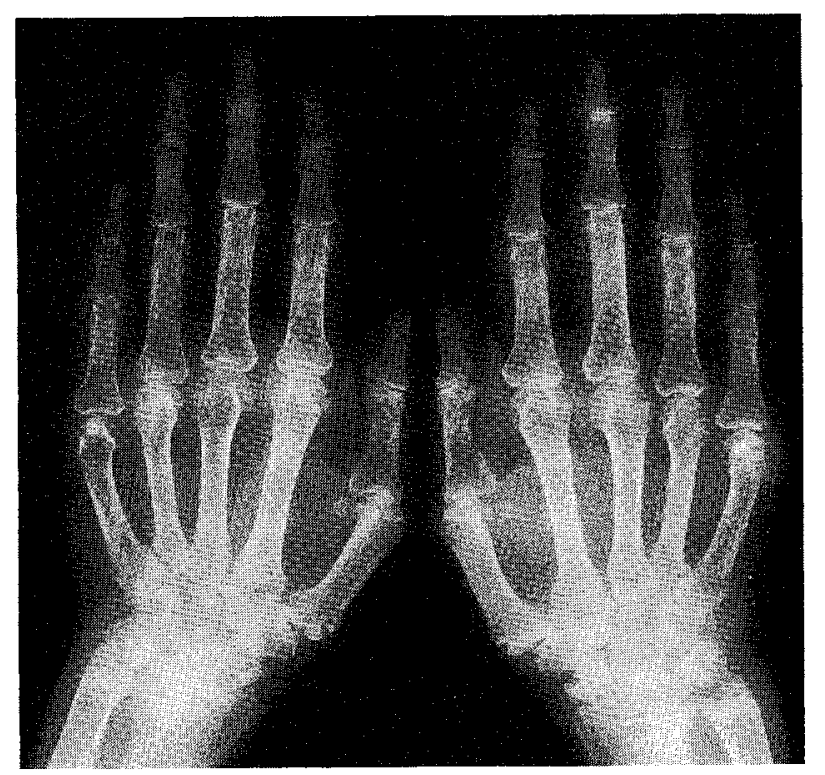

Fig. 2. Roentgenogram of both hands taken on March 8, 1991, showing typical crosive changes. of HLA analysis disclosed that the present patient possessed the combination of HLA-DR4 and HLA-Bw54 which has been reported to be associated with RA in the Japanese population (17), indicating that she was genetically susceptible to RA.

\section{Discussion}

We describe a patient who developed RA after posttransfusion $\mathrm{HCV}$ infection. The association of arthritis with viral hepatitis has been well documented (5-12). However, polyarthritis in patients with acute viral hepatitis usually emerges during the prodrome of hepatitis and subsides with the development of the typical manifestation of hepatitis, leaving no joint deformity (6). In chronic active viral hepatitis, polyarthralgia may present with the early systemic manifestations of the disease (6). The polyarthritis noted in the present patient differs from such arthritides in patients with viral hepatitis in a number of aspects. First, the polyarthritis in the present patient developed after the hepatitis had subsided. Secondly, the polyarthritis was long lasting and progressive to result in joint destruction. Finally, although the serum rheumatoid factor was positive along with the presence of active synovitis, our patient showed negative serum rheumatoid factor during the phase of active hepatitis without joint manifestations. Together with these findings, this patient fulfilled the 1987 revised American Rheumatism Association criteria for rheumatoid arthritis (18), indicating that the joint manifestations in our patients are due to the development of RA. Recently, human T cell leukemia virus type 1 (HTLV-I) has been found to cause chronic progressive synovitis resembling RA (19). However, the test for anti-HTLV-I antibody was negative in the present patient, obviating the possibility that the joint manifestations of this patient 
might be caused by HTLV-I infections.

Although the relationship between hepatitis $B$ and synovitis has been extensively studied, there has been only one case report describing the occurrence of RA as a sequel to HBs Ag hepatitis by Morris and Stevens (13). However, the possibility of double infection of HBV and HCV could not be excluded in their patient. On the other hand, there has been a report that 2 of 30 patients with RA without a history of hepatitis showed the positive serum anti-HCV antibody (20). It is therefore possible that HCV may contribute to the development of RA.

Although the etiology of RA is still unknown, there is a hypothesis that the disease may be triggered by one or more foreign antigens invading genetically susceptible individuals (1). The close association of HLA-DR4 with RA has been well appreciated irrespective of the race (2-4). As to the Japanese RA patients, however, combination of HLA-DR4 and HLA-Bw54 has been frequently observed (17). Interestingly, the present patient possessed a combination of HLA-DR4 and HLABw54, indicating that she was genetically susceptible to RA. Therefore, it is suggested that HCV may trigger the development of RA in genetically susceptible individuals. Of course, we cannot exclude the possibility that $\mathrm{HCV}$ infection and the development of RA might have occurred in this patient by chance. Further studies are necessary to clarify the precise role of $\mathrm{HCV}$ in the development of RA.

This work was partially supported by a 1990 Grant No. 01570354 from the Ministry of Education, Culture and Science of the Japanese Government

Acknowledgments: The authors wish to thank Miss Chise Kawashima for her assistance in preparing the manuscript.

\section{References}

1) Utsinger PD, Zvaifler NJ, Ehrlich GE. Rheumatoid arthritis. Philadelphia, Lippincott, 1985.

2) Karr RW, Rodey GE, Lee T, Schwartz BD. Association of HLA-DRw4 with rheumatoid arthritis in black and white patients. Arthritis Rheum 23: 1241, 1980.

3) Stastny P. Association of the B-cell alloantigen DRw4 with rheumatoid arthritis. N Engl J Med 298: 869, 1978.

4) Maeda H, Juji T, Mitsui H, Sonozaki H, Okitsu K. HLA DR4 and rheumatoid arthritis in Japanese people. Ann Rheum Dis 40: $299,1981$.

5) Alpert E, Isselbacher KJ, Schur PH. The pathogenesis of arthritis associated with viral hepatitis. Complement-component studies. N Engl J Med 285: 185, 1971.

6) Duffy J, Lidsky MD, Sharp JT, et al. Polyarthritis, polyarteritis and hepatitis B. Medicine 55: 19, 1976.

7) Schumacher HR, Gall EP. Arthritis in acute hepatitis and chronic active hepatitis. Pathology of the synovial membrane with evidence for the presence of Australia antigen in synovial membranes. Am J Med 57: 655, 1974.

8) Onion DK, Crumpacker CS, Gilliland BC. Arthritis of hepatitis associated with Australia antigen. Ann Intern Med 75: 29, 1971.

9) McCarty DJ, Ormiste V. Arthritis and HB Ag-positive hepatitis. Arch Intern Med 132: 264, 1973.

10) Wands JR, Mann E, Alpert E, Isselbacher $\mathrm{KJ}$. The pathogenesis of arthritis associated with acute hepatitis-B surface antigenpositive hepatitis. Complement activation and characterization of circulating immune complexes J Clin Invest 55: 930, 1975.

11) Fernandez R, McCarty DJ. The arthritis of viral hepatitis. Ann Intern Med 74: 207, 1971.

12) Fitz JG, Petri M, Hellmann D. Chronic active hepatitis presenting with rheumatoid nodules and arthritis. J Rheumatol 14: 595, 1987.

13) Morris EL, Stevens MB. Rheumatoid arthritis-A sequel to $\mathrm{HBsAg}$ hepatitis. Am J Med 64: 859, 1978.

14) Choo QL, Kuo G, Weiner AJ, Overby LR, Bradley DW, Houghton $M$. Isolation of a cDNA clone derived from a bloodborne non-A, non-B viral hepatitis genome. Science 244: 359, 1989.

15) Kuo G, Choo QL, Alter HJ, et al. An assay for circulating antibodies to a major etiologic virus of human non- $A$, non- $B$ hepatitis. Science 244: 362, 1989.

16) Choo QL, Weiner AJ, Overby LR, Kuo G, Houghton M, Bradley $D W$. Hepatitis $C$ virus: The major causative agent of viral non-A, non-B hepatitis. Br Med Bull 46: 423, 1990.

17) Ohta N, Nishimura YK, Tanimoto $K$, et al. Association between HLA and Japanese patients with rheumatoid arthritis. Hum Immunol 5: 123, 1982.

18) Arnett FC, Edworthy SM, Bloch DA, et al. The American Rheumatism Association 1987 revised criteria for the classification of rheumatoid arthritis. Arthritis Rheum 31: 315, 1988.

19) Nishioka K, Maruyama I, Sato K, Kitajima I, Nakajima $Y$, Osame M. Chronic inflammatory arthropathy associated with HTLV-I. Lancet i: 441, 1989.

20) Tanaka K, Kobayashi $S$, Isobe $Y$, et al. Anti-hepatitis $C$ virus antibody in sera from patients with rheumatic diseases (in Japanese). The 34th annual meeting of the Japan Rheumatism Association, Book of Abstract, p. 195, 1990 (Abstract). 